\title{
El magistral ejemplo de Cervantes
}

\author{
José María RodríGuez MÉNDEZ
}

Siempre que me acerco a la figura de Miguel de Cervantes, lo primero que siento es un inmenso respeto y una gran unción por encima de mi aprecio literario que es inconmensurable. Y luego mi agradecimiento por su compañía a través de los años.

Ha habido para mí tres grandes figuras de las letras universales que me han venido acompañando en mi periplo vital, acompañado y fortalecido. Son tres inmensas figuras de las letras y del arte, pero fundamentalmente tres santos y tres ejemplos, para mí, desgraciadamente inimitables. Pero han sido, por supuesto llamadas a mi atención, que me han marcado aunque tan levemente.

Estos tres han sido Juan, Teresa y Miguel, por este orden. Los dos primeros fueron también canonizados, mientras el tercero ha quedado como ejemplo social y cultural, más cercano a nosotros, aunque también aparece su aureola de santo, a través de esa "saudade" que parece emanar de toda su obra, como un perfume de resignación y esperanza que algo tienen que ver con su apellido lusitano.

Y ahora que estoy terminando mi vida, siento a don Miguel de Cervantes Saavedra cada día más cerca de mí, confortándome y estimulándome con su "ejemplaridad".

Efectivamente, para mí no ha habido escritor más ejemplar que Cervantes. Ejemplar por cercano, por puro, por servicial y sufrido, por su identificación con las tierras y personajes de nuestra España, por su camino vital llevado con tanta resignación y sabiduría. No, de ninguna manera quisiera hablar por hablar a propósito de esta cercanísima figura, que por eso, por su cercanía, parece ser propiedad de todos, como se vio durante el pasado año de conmemoración cervantina. 
Cervantes siempre, pero más en estos momentos, se alza ante nosotros como el faro que debiera guiarnos a todos, o como la nueva galera que a través de los mares nos pueda salvar del terrible naufragio que ya asoma por el horizonte.

En esta España que hoy estamos recorriendo, una España sin Dios y sin honor ¿cómo no volver los ojos hacia la ejemplaridad cervantina? Precisamente, un hermoso manojo de sus obras llevan el título de "Ejemplares". Fuera él mismo, o sus estudiosos o exégetas, quienes titularon así sus obras cortas, la verdad es que sus personajes al igual que su autor serán siempre para nosotros auténticos ejemplares humanos, capaces de servir de modelo ético y humano.

Hay algo que siempre me ha subyugado en el comportamiento del gran escritor y es su manera de soportar el sufrimiento, sin manifestar quejas personales y dispersando ese sufrimiento por la vía del humor, que vino a convertirse en el temple español por excelencia que siempre fue el sufrir y a la vez perdonar a nuestro prójimo, como Cristo nos enseñó.

Don Miguel soportó con enorme ejemplaridad lo que hoy nosotros no acabamos de soportar. Se vio como nosotros agobiado por la presión de unos imperios insoportables. Supo lo que es la lucha racial, que bebió a través de su propia sangre. Fue esclavo y prisionero del infiel, como al final de su vida sería injuriado, calumniado, teniendo que ganarse la vida como soldado de fortuna y recaudador de unos impuestos que le llevarían a la cárcel "donde toda molestia tiene su asiento" y en fin la injusticia despiadada recayó sobre él con toda su furia. Pero siguió con su estoicismo adelante, puesto ya el pie en el último estribo.

Comprensión y sabiduría en fin. Sobre estas dos realidades puedo forjar naturalmente una obra eterna sin parangón, obra hecha para nosotros, para los que respiramos el aire mefítico que él respiró.

Y todo eso nos vino envuelto en una lengua castellana que se hizo universal. Hoy el nombre de Miguel de Cervantes viene a significar eso: Lengua y Literatura española y en eso consiste su santidad que le aproximaría a los otros dos, Juan de la Cruz y Teresa de Jesús, con los que le venero. A los tres debemos el gran regalo de una lengua universal, que por encima de todo nos redime y nos rescata de nuestros enemigos, esos que hoy quisieran arrebatárnoslo todo... Pero no podrán jamás con esa divina lengua. 